\title{
Uma Análise do Fenômeno Constitucional a partir do Reconhecimento das Uniões Homoafetivas como Família pelo Supremo Tribunal Federal Brasileiro
}

\author{
Un Análisis del Fenómeno Constitucional a partir del Reconocimiento de \\ las Uniones Homoafectivas como Familia por el Supremo Tribunal \\ Federal Brasileño
}

\author{
An Analysis of the Constitutional Phenomenon from the Recognition of \\ Homoaffective Unions as Family by the Brazilian Federal Supreme Court
}

\author{
Denise Regina Quaresma da Silva ${ }^{1}$ \\ Alberto Barreto Goerch ${ }^{2}$ \\ Thaís Zanetti de Mello Moretto ${ }^{3}$
}

\begin{abstract}
Resumo
Este estudo, de cunho teórico, aborda o ativismo judicial frente às faces de interpretação e compreensão jurídica do fato concreto, visando formar precedentes e provimentos mais justos e humanitários, focado na decisão do Supremo Tribunal Federal brasileiro (STF) que amplia o reconhecimento de união estável prevista na Constituição da República Federativa do Brasil de 1988 e no Código Civil de 2002. Abordar-se-á o conceito de ativismo judicial e suas controvérsias, problematizando o ativismo judicial como um instrumento de concretização de direito fundamental, tendo por objetivo elucidar a questão pendente da união homoafetiva devido à evolução da sociedade em contrapartida com a lenta evolução do direito, apontando o ativismo judicial como um fenômeno da jurisdição constitucional. Inicialmente apresenta-se o conceito de ativismo judicial, ocupando-se com os princípios constitucionais processuais, seguido por um segundo capitulo que irá tratar das nuances da união homoafetiva no Brasil. Metodologicamente, empregou-se a abordagem dedutiva, bem como o procedimento histórico-comparativo e da técnica de pesquisa de documentação indireta bibliográfica. Conclui-se que a união homoafetiva vem ganhando cada vez mais força perante a sociedade atual, muito embora tenhamos ainda uma postura conservadora dos Poderes Legislativo e Executivo; fazendo assim com que as demandas positivas nesse aspecto, acabem por fazer esse grupo sentir-se protegido pelo Estado na figura do Poder Judiciário. A sociedade alcança assim, uma maior visibilidade em prol do controle positivo, na intenção de se repelir atitudes discriminadoras e agressivas perante este grupo social fundado em ações positivas (ativistas) que garantam o respeito à diversidade sexual.
\end{abstract}

Palavras-Chave: Ativismo judicial; diversidade sexual; jurisdição constitucional; uniões homoafetivas; Educação em Direitos Humanos.

\section{Resumen}

Este estudio, de cuño teórico, aborda el activismo judicial frente a las caras de interpretación y comprensión jurídica del hecho concreto, visando formar precedentes y procesos más justos y humanitarios, enfocado en la

\footnotetext{
${ }^{1}$ Pesquisadora do Programa de Pós Graduação em Diversidade Cultural e Inclusão Social da Universidade Feevale e do PPG em Educação da Universidade La Salle; denisequaresma @ feevale.br

${ }^{2}$ Doutorando no Programa de Pós Graduação em Diversidade Cultural e Inclusão Social da Universidade

Feevale, Bolsista CAPES; betogoerch@ gmail.com

${ }^{3}$ Doutoranda no Programa de Pós-Graduação em Diversidade Cultural e Inclusão Social da Universidade

Feevale; mzm.thais@gmail.com
} 
decisión del Supremo Tribunal Federal brasileño (STF) que amplía el reconocimiento de unión en el Código Civil de 2002. Se abordará el concepto de activismo judicial y sus controversias, problematizando el activismo judicial como un instrumento de concreción de derecho fundamental, con el objetivo de elucidar la aplicación de la ley, la cuestión pendiente de la unión homoafectiva debido a la evolución de la sociedad en contrapartida con la lenta evolución del derecho, apuntando al activismo judicial como un fenómeno de la jurisdicción constitucional. Inicialmente se presenta el concepto de activismo judicial, ocupándose con los principios constitucionales procesales, seguido por un segundo capítulo que tratará de los matices de la unión homoafetiva en Brasil. Metodológicamente, se empleó el enfoque deductivo, así como el procedimiento históricocomparativo y de la técnica de investigación de documentación indirecta bibliográfica. Se concluye que la unión homoafetiva viene ganando cada vez más fuerza ante la sociedad actual, aunque todavía tengamos una postura conservadora de los Poderes Legislativo y Ejecutivo; haciendo así que las demandas positivas en ese aspecto, acaben por hacer que ese grupo se sienta protegido por el Estado en la figura del Poder Judicial. La sociedad alcanza así una mayor visibilidad en pro del control positivo, en la intención de rechazar actitudes discriminatorias y agresivas ante este grupo social fundado en acciones positivas (activistas) que garanticen el respeto a la diversidad sexual.

Palabras clave: Activismo judicial; diversidad sexual; jurisdicción constitucional; uniones homoafectivas; Educación en Derechos Humanos.

\begin{abstract}
This theoretical study deals with judicial activism in the face of interpretation and legal understanding of the concrete fact, aiming to form precedents and more just and humane trials, focused on the decision of the Federal Supreme Court (STF) established in the Constitution of the Federative Republic of Brazil of 1988 and in the Civil Code of 2002. The concept of judicial activism and its controversies will be discussed, problematizing judicial activism as an instrument for the realization of fundamental rights, with the objective of elucidating the pending issue of the homoafetive union due to the evolution of society in counterpart with the slow evolution of law, pointing to judicial activism as a phenomenon of constitutional jurisdiction. Initially, the concept of judicial activism is presented, dealing with constitutional procedural principles, followed by a second chapter that will deal with the nuances of the homoafetive union in Brazil. Methodologically, we used the deductive approach, as well as the historical-comparative procedure and the research technique of indirect bibliographical documentation. It is concluded that the homoaffective union has been gaining more and more force in the present society, even though we still have a posture conservative of the Legislative and Executive Powers; thus making the positive demands in this regard, end up making this group feel protected by the State in the figure of the Judiciary. Society thus achieves greater visibility in favor of positive control, with the intention of repelling discriminatory and aggressive attitudes towards this social group founded on positive actions (activists) that guarantee respect for sexual diversity.
\end{abstract}

Keywords: Judicial activism; sexual diversity; constitutional jurisdiction; homoaffective unions; Education in Human Rights.

\title{
1. Introdução
}

O ativismo judicial é um tema de grande relevância social da esfera jurídica, contudo, apesar de ser um fenômeno socialmente necessário em determinados casos, sua concretização esbarra em duas grandes polêmicas fundadas na concretização dos direitos constitucionais e na legitimidade que o judiciário possui para exercer tal conduta.

A necessidade de abordagem do tema neste artigo funda-se no entendimento das variadas nuances que possui, bem como o seu exercício tem colaborado para o surgimento de 
precedentes mais humanitários, desmistificando o processo como um instrumento de analise meramente formal, sendo as transformações ocorridas na sociedade um meio de influência para a evolução do Direito, como forma de desconstrução e reconstrução de paradigmas firmados no passado, visando o uso de técnicas valorativas para conferir a aplicabilidade das normas.

O fenômeno constitucional do ativismo judicial, focado na decisão que amplia o significado de união estável, verifica-se a necessidade da abordagem do mesmo, devido à união homoafetiva ainda ser um tema pouco discutido no âmbito social, ainda que, a evolução da sociedade tenha quebrado alguns tabus e considere-se mais livre para "amar quem quiser", podemos analisar a partir do tema abordado se realmente é considerada justa toda a forma de amor, demonstrando a necessidade da interpretação da norma constitucional para a concretização do direito à união estável, visando uma maior compreensão na Constituição Federal de 1988, a fim de atender a sociedade em suas diversas nuances e problemáticas, promovendo um sistema judicial mais justo e inteirado dos problemas sociais enfrentados pelos homossexuais, devido a tratar-se de uma constituição anterior à problemática social brasileira tratada no presente trabalho, cabe-se uma interpretação ampla dos conceitos constitucionais previstos na mesma, para a melhor compreensão da sociedade como um grupo social, a fim de diminuir a compactação em grupos determinados.

Para melhor compreensão, o presente artigo será divido em dois capítulos, tratando respectivamente da conceituação do fenômeno ativismo judicial, com subdivisão tratando dos princípios constitucionais do processo civil, seguido de um capítulo dedicado ao entendimento do direito à união homoafetiva e a influência do ativismo judicial nessa decisão, trazendo elementos que possibilitem a analise crítica da atuação do Poder Judiciário. Metodologicamente, trata-se da análise de fundamentos doutrinários para a compreensão do fenômeno em questão.

\section{O fenômeno do ativismo judicial e formas de interpretação}

O ativismo judicial consiste na criação de precedentes por tribunais na avaliação das singularidades do caso concreto, antecipando-se, na maioria das vezes, à formulação de lei especifica que se encaixe no caso, baseia-se na transformação da realidade por meio da ação prática, sendo uma doutrina ou argumentação que priorize a prática efetiva de transformação da realidade em oposição à atividade jurisdicional puramente teórica e técnica. Considera-se o ativismo judicial como uma postura, forma de agir de determinado magistrado diante de 
novas necessidades onde as normas não se mostram suficientes ou dão ensejo a interpretação de texto de lei, através de mecanismos como a hermenêutica e princípios fundamentais, para uma melhor adaptação do texto escrito em situações reais. Segundo GRANJA (2018):

O termo ativismo judicial, conquanto se refira ao meio jurídico, nasceu com a publicação de um artigo na revista americana Fortune, pelo historiador americano Arthur Schlesinger, numa reportagem sobre a Suprema Corte dos Estados Unidos, no qual ele traçou o perfil dos nove juízes da Suprema Corte. Desde então, o termo vem sendo utilizado, normalmente, em uma perspectiva crítica quanto à atuação do Poder Judiciário.

Pode-se ainda falar em energia diante das necessidades que dão abertura às interpretações de texto de lei, sendo esse o momento do magistrado demonstrar a energia emanada dos tribunais para a resolução das necessidades advindas de omissão ou lentidão legislativa. Ainda, segundo GRANJA (2018) considera-se "ativista o juiz que: a) use o seu poder de forma a rever e contestar decisões dos demais poderes do estado; b) promova, através de suas decisões, políticas públicas; c) não considere os princípios da coerência do direito e da segurança jurídica como limites à sua atividade". Ademais, se uma norma permite uma interpretação proativa do seu texto, cabe ao juiz expandir seu alcance e sentido.

O ativismo judicial faz parte da ascensão institucional do Poder Judiciário, decorrente do modelo constitucional adotado com a Constituição Federal de 1988, portanto, não é um fenômeno isolado ou um mero exercício deliberado de vontade política. Acompanha as inúmeras mudanças do Direito Constitucional, as quais ocasionaram uma transformação no modo de pensar e praticar o direito (LOPES, 2010).

Segundo BARROSO (2018), normalmente o ativismo judicial se instala em situações de retração do Poder Legislativo, assim fazendo com que as demandas sociais sejam atendidas com mais efetividade. A ideia de ativismo judicial está atrelada a uma participação mais ampla e ativa do Poder Judiciário na concretização dos direitos constitucionais e valores que lhes são atribuídos, tendo maior intervenção no campo de atuação do Poder Executivo e Legislativo.

Assim, o ativismo judicial procura demonstrar o máximo das possibilidades do texto constitucional, porém sem invadir o espaço da criação livre e nova do Direito. Com a expansão do ativismo judicial, conseguimos observar uma aproximação do sistema judiciário Brasileiro com o Europeu, aproximando Common Law e Civil Law através da atividade de criação de precedentes jurisprudenciais, viabilizando o espaço necessário para interpretações legais do texto, observando-se uma ampliação do controle normativo. Para CITTADINO (2002), cabe citar que a ampliação normativa foi favorecida pela Constituição Federal de 1988, que ao incorporar princípios fundamentais, incorporar um estado Democrático de 
Direito e estabelecer fundamentos do Estado, viabiliza uma ação judicial que cabe métodos interpretativos para a legitimação de direitos sociais, sendo então considerado um reforço da lógica democrática. Contudo, a partir da breve analise feita até o momento, nota-se o nascimento do fenômeno da judicialização das relações sociais, tornando-se assim de suma importância que o judiciário se manifeste perante as demandas trazidas a si, proporcionando assim a postura ativista do juiz perante as limitações encontradas em demandas fundadas em uma nova interpretação de um direito inerente à pessoa.

Mesmo que, na maioria das vezes, o ativismo judicial contrarie o sistema de freios e contrapesos, expondo as dificuldades encaradas pelo Poder Legislativo, o mesmo engloba em sua atuação o atendimento de demandas sociais que não puderam ser supridas pelo parlamento, dando maior saneamento processual ao usar a interpretação constitucional para analisar as problemáticas que ainda não foram solucionadas.

Contudo, ainda não há a pacificação entre a doutrina sobre esse fenômeno, questionando-se sobre os limites ultrapassados pelo judiciário, devido a cada poder ter o dever de exercer suas funções dentro do seu limite de atuação, não devendo interferir na atuação dos outros poderes. A interpretação criativa dos tribunais que procuram conciliar os princípios fundamentais constitucionais, acolhendo um processo de luta por direitos e da conciliação dos princípios constitucionais de forma produtiva a alcançar todos os indivíduos a quem a lei é destinada.

Desta maneira evidencia-se que o Poder Judiciário acaba por atuar quando há vácuo normativo, especialmente na função legislativa, assim, o Supremo Tribunal Federal (STF) vem sendo convocado a pronunciamento perante a omissão legislativa, porém considera-se que algumas das atitudes extrapolam o limite aceitável pelo convencionado como função jurisdicional, dizendo-se assim que há uma intromissão indevida do Poder Legislativo, ferindo o principio da separação dos três poderes, a democracia e o estado democrático de direito, assim então fomentando uma insegurança jurídica.

\footnotetext{
(...) a crítica se funda na alegação de que o Poder Judiciário não possui legitimidade democrática para, em suas decisões, insurgir-se contra os atos instituídos pelos poderes eleitos pelo povo. Assim, o Poder Judiciário, com seus membros não eleitos, não poderia demudar ou arredar leis elaboradas por representantes escolhidos pela vontade popular. Este poder não teria legitimidade para isso. É o que se chama de desafio contra majoritário, interferindo diretamente no poder regulatório e ferindo o princípio da separação dos poderes. Ou seja, onde estaria a sua legitimidade para proscrever decisões daqueles que desempenham mandato popular, que foram escolhidos pelo povo (CARMONA, 2015).
}

Portanto, o lado negativo do ativismo judicial paira sobre o desrespeito a divisão dos três poderes, fazendo assim com que falta de limites do Poder Judiciário, acabe por adentrar 
nos limites do Poder Legislativo gerando um fenômeno de perda de judicialização, devido às decisões serem baseadas em um pensamento individual, mesmo que o provimento acabe por ser considerado convincente e necessário perante a sociedade, ainda não se há um conceito formado de justiça, portanto, trazendo a tona uma grande insegurança jurídica perante demandas recebidas em juízo, gerando assim, devido ao deslumbramento com a possibilidade de decisões mais humanitárias, o esquecimento da fundamentação racional nos julgamentos, tornando os princípios Constitucionais meras marionetes nas mãos do Poder Judiciário, ferindo o Estado Democrático de Direito e a democracia, devido à permissibilidade de um juiz, não eleito pelo povo, imponha suas preferências e valores aos julgados, atentando contra a segurança jurídica, tornando o direito imprevisível, muitas vezes gerando precedentes com valores meramente morais, com pouca fundamentação, tornando-se precedentes rasos e incongruentes (CARMONA, 2015).

\section{Os princípios constitucionais do processo civil e o ativismo judicial}

O exercer do ativismo judicial representa uma aproximação do Direito Constitucional com o Direito Processual civil, sendo usado como forma de concretização de direitos fundamentais, assim, procurando alcançar sintonia fina com a constituição como prevê expressamente a exposição de motivos do projeto do Novo Código de Processo Civil. Contudo, a concretização do direito à razoável duração do processo vai de encontro com a imprecisão e com as obscuridades do principio, sendo evidenciado apenas com o caso concreto.

Para que exista uma decisão justa, o juiz deverá proceder a uma valida individualização e interpretação da norma aplicada ao caso concreto, mas também, e, sobretudo, proceder a uma reconstrução verdadeira e racionalmente controlável do caso concreto, ou melhor, das afirmações factuais que o acompanham. A justiça da decisão, caracterizada pelo seu grau de aproximação à realidade dos fatos, coloca em evidencia a função do processo como lugar de acertamento da verdade. Por isso é necessário que a decisão esteja fundada não apenas na boa interpretação das regras legais, mas também na reconstrução que mais se aproxime da verdade dos fatos (NEVES, 2012).

Entretanto, a conceituação do que é "razoável” está interligada a concretude do caso real, ocorrendo uma incerteza sobre os limites da razoável duração processual, assim cabendo ao judiciário observar a aplicação de tal principio, esbarrando nas rigorosidades legais e formais do Processo Civil, necessitando a observância do tradicionalismo processual para a quebra de paradigmas a fim de proporcionar uma tutela jurisdicional mais rápida efetiva, sendo sua função servir de instrumento para concretização de direitos fundamentais. Portanto, 
cabe ao Judiciário estabelecer o limite do razoável como método de concretização de preceitos fundamentais, deixando para trás as limitações burocráticas ligadas ao formalismo do Processo Civil.

Vive-se um contexto social onde o judiciário é constantemente provocado com questões de alta complexidade na pendência de decisões, havendo a necessidade de interferência do mesmo em questões que o Legislativo ainda não criou norma, bem como, o juiz não pode deixar de apreciar demanda por falta de norma correspondente, assim usa-se a interpretação da norma como forma de encontrar soluções adequadas às demandas, como autoriza a Lei de Introdução às Normas do Direito Brasileiro, em seu artigo $4^{\circ}$, assim existindo uma legitimação para o Judiciário agir antes de o Legislativo criar norma correspondente às necessidades da sociedade, que evolui de forma constante, fazendo com que o Direito não consiga acompanhar tal evolução, tampouco sendo possível prever todas as situações que poderão ser controvertidas ao longo do tempo, sendo extremamente necessária a adequação das normas à realidade fática. Segundo NEVES (2012) a sociedade não busca apenas uma aplicação puramente dedutiva de textos de lei, mas sim uma atuação ativa dos juízes, a fim de haver provimentos mais justos e próximos à realidade, sendo essa atuação totalmente relevante para desvincular o processo do conceito meramente técnico, e torná-lo um instrumento de uso da sociedade.

É de se afirmar ainda, que efetivar a função social do processo é o objetivo maior do ativismo judicial, assegurando que as pretensões jurídicas e ideológicas sejam cumpridas através de um instrumento que possibilite aos cidadãos recorrer ao Judiciário quando se tem ameaça a direito, interligando-se assim com o principio fundamental do acesso à justiça, trazendo mais força de atuação dos ativistas judiciais, devido ao cumprimento desses principio fundamental que guia o Estado Democrático de Direito, sendo o ponto principal a capacidade de assegurar direitos ao caso concreto para que haja a resolução satisfatória de demandas que necessitam de uma visão abrangente das normas constitucionais, devido à complexidade do objeto da ação em questão, assim sendo oferecida uma melhor e mais justa prestação jurisdicional (BARROSO, 2018).

O processo justo é fruto de uma produção jurídico cultural, não significando apenas que o cidadão tem o direito de ser ouvido em juízo ou ingressar em juízo, tornando-se maior que as formalidades do Estado Democrático de Direito, sendo analisado o processo da sua perspectiva material e formal tornando-se complementares as duas esferas, pois entender o processo justo significa analisar as duas esferas em conjunto, afim de não tornar o processo um instrumento sem eficácia, visto apenas por uma perspectiva formalista, tampouco tornar 
um instrumento meramente formal desconsiderando as funções do processo. O que é pretendido é justiça processual vinculado à decisão efetiva na resolução da lide, assim passando de "processo legal" para "processo justo".

\section{Considerações sobre as uniões homoafetivas e o respeito à diversidade sexual}

No século XXI, a sociedade notoriamente vem evoluindo a pequenos passos, gerando situações que os poderes da Republica não detém condições de previsão, fazendo-se assim com que o Poder Judiciário enfrente constantemente fatos novos advindos das diversas interações sociais, modificando-se assim vários conceitos que não se encaixam mais com a realidade vivida.

Como é visto, considera-se a Constituição da República Federativa do Brasil a lei máxima que rege o país, em seu primeiro artigo versa sobre o respeito à dignidade da pessoa humana, que implica o uso do princípio da isonomia como uma energia potencializadora afim da transformação social e das relações jurídicas, implicando então que as regras de união estável, prevista para pessoas heterossexuais, sejam aplicadas de mesma maneira para casais homossexuais.

\footnotetext{
Ainda que se conceitue família como uma relação interpessoal entre um homem e uma mulher, tendo por base o afeto, necessário reconhecer que há relacionamentos que, mesmo sem a diversidade de sexos, são cunhados também por um elo de afetividade. Os relacionamentos afetivos, independentemente da identificação do sexo do par - se formados por homens e mulheres, ou só por mulheres, ou só por homens - são alvos de proteção, em razão da imposição constitucional do respeito à dignidade humana (CHAVES, 2012).
}

Pode-se considerar ato extremamente atentatório à dignidade da pessoa humana o fato de não ser permitido uma união estável a casais do mesmo sexo, pois se consideram as uniões o relacionamento fundado em um vínculo afetivo que gera desdobramentos na vida social e psicológica do individuo, havendo assim a necessidade de mudanças de acordo com as manifestações sociais de novos fenômenos desconhecidos pela legislação, fazendo-se assim com que a Constituição Federal não deixe o direito estanque perante a evolução social, relativizando algumas das aplicações de seus institutos, visando assim um direito que acompanhe as mudanças sociais e os novos institutos familiares que acabam por surgir devido o modernismo social.

A falta de reconhecimento em ações que tenham por objeto uniões homoafetivas enseja uma renegação de situações sociais existentes, bem como a contemplação de injustiças causadas pela falta de reconhecimento legislativo, gerando-se assim uma invisibilidade das 
causas sociais, visto que não cabe ao juiz julgar as opções pessoais e individuais das partes, atendo-se apenas as questões propostas em juízo, fazendo-se assim uma solução que seja considerada justa (CHAVES, 2012).

Sendo o direito baseado na sociedade e em seu comportamento, seus institutos não devem ficar apartados da sociedade, visto que há uma intersecção entre a esfera social e a esfera jurídica, gerando-se assim o dever do poder legislativo, do poder judiciário e ainda dos operadores do direito de não haver casos de omissão devido às transformações sociais, mantendo-se assim a norma atualizada em prol dos comportamentos sociais em destaque.

Ainda vale ressaltar que é dever do Poder Legislativo adequar a lei vigente ao entendimento do Poder Judiciário, pois assim eliminam-se as dificuldades e inseguranças jurídicas encontradas perante as demandas propostas por casais homoafetivos, gerando-se assim precedentes e estímulos para a chegada de novas demandas relacionadas a esse grupo social, causando assim um grande impacto na sociedade brasileira, devido ao reconhecimento dos direitos sociais e fundamentais do grupo em questão.

Cumpre ao Poder Legislativo exercer o papel que lhe cadê para adequar as disposições contidas no Código Civil ao entendimento consagrado pela Suprema Corte, como proposto no projeto de lei da senadora Marta Suplicy, contribuindo assim para o aumento da segurança jurídica e, em ultima análise, a disseminação da pacificação social (AQUINO, 2017).

Perante a omissão do legislador, deve então o Poder Judiciário aplicar a determinação constante no Artigo $4^{\circ}$ da Lei de Introdução as Normas Brasileiras, não podendo deixar de julgar demandas por falta de legislação, gerando-se assim, perante o fenômeno do ativismo judicial, decisões visando o reconhecimento da união homoafetiva como instituto.

\section{Preceitos e fundamentos do julgamento de reconhecimento das uniões homoafetivas como família pelo Supremo Tribunal Federal brasileiro}

A decisão referente respeito do reconhecimento da união homoafetiva encontram-se na Ação Direta de Inconstitucionalidade 4.277 (ADI 4.277) e na Arguição de Descumprimento de Preceito Fundamental 132 (ADPF 132), visando-se então a partir desses instrumentos constitucionais combater-se a prática de atos atentatórios a dignidade da pessoa humana.

Primeiramente, tratando-se da ADI 4.277, a mesma foi proposta em 22 de julho de 2009, sob as alegações fundadas na inexistência de regulamentação legal, perante isso, sendo impedido o exercício de direitos fundamentais por parte dos homossexuais, sendo os argumentos de impedimento em maior parte de cunho religioso, indo contra o Estado Laico. 
Ainda alegando-se o descumprimento do principio da dignidade da pessoa humana. Destacase a importância do comentário tecido pelo Ministro ${ }^{4}$ Ayres Britto, no julgamento desta mesma ADI 4.277, acorrido em 5 de maio de 2011.

PROIBIÇÃO DE DISCRIMINAÇÃO DAS PESSOAS EM RAZÃO DO SEXO, SEJA, NO PLANO DA DICOTOMIA HOMEM/MULHER (GÊNERO), SEJA NO PLANO DA ORIENTAÇÃO SEXUAL DE CADA QUAL DELES. A PROIBIÇÃO DO PRECONCEITO COMO CAPÍTULO DO CONSTITUCIONALISMO FRATERNAL. HOMENAGEM AO PLURALISMO COMO VALOR SÓCIO-POLÍTICO-CULTURAL. LIBERDADE PARA DISPOR DA PRÓPRIA SEXUALIDADE, INSERIDA NA CATEGORIA DOS DIREITOS FUNDAMENTAIS DO INDIVÍDUO, EXPRESSÃO QUE É DA AUTONOMIA DE VONTADE. DIREITO À INTIMIDADE E À VIDA PRIVADA. CLÁUSULA PÉTREA. O sexo das pessoas, salvo disposição constitucional expressa ou implícita em sentido contrário, não se presta como fator de desigualação jurídica. Proibição de preconceito, à luz do inciso IV do art. $3^{\circ}$ da Constituição Federal, por colidir frontalmente com o objetivo constitucional de "promover o bem de todos". Silêncio normativo da Carta Magna a respeito do concreto uso do sexo dos indivíduos como saque da kelseniana "norma geral negativa", segundo a qual "o que não estiver juridicamente proibido, ou obrigado, está juridicamente permitido". Reconhecimento do direito à preferência sexual como direta emanação do princípio da "dignidade da pessoa humana": direito a autoestima no mais elevado ponto da consciência do indivíduo. Direito à busca da felicidade. Salto normativo da proibição do preconceito para a proclamação do direito à liberdade sexual. O concreto uso da sexualidade faz parte da autonomia da vontade das pessoas naturais. Empírico uso da sexualidade nos planos da intimidade e da privacidade constitucionalmente tuteladas. Autonomia da vontade. Cláusula pétrea (BRASIL, 2011).

A conclusão do julgamento (BRASIL, 2011), trouxe a tona a questão em torno do ativismo judicial, acreditando-se que a partir do momento da conclusão do julgamento, houve a criação de uma norma de conduta, que é tarefa do Poder Legislativo, pelo Poder Judiciário, suscitando a questão referente a omissão legislativa em benefício da sociedade moderna, acreditando-se que o Poder Judiciário só tomou tal iniciativa devido a cobrança por parte da sociedade, assim reafirmando a tese já pacificada de que "o Poder Judiciário age mediante provocação".

Nota-se que a omissão legislativa é uma ameaça aos direitos e garantias previstos na Constituição de 1988. Ela decorre, principalmente, do fato de que os integrantes do Legislativo são eleitos, e, por isso, se preocupam com sua reeleição e aprovação por parte da sociedade. Para tal, evitam elaborar leis de assuntos polêmicos que possam gerar a desaprovação de grande parcela da sociedade (TEIXEIRA, 2016).

Contudo, cabe-se afirmar que o ativismo contido nesta decisão foi um modo encontrado de interpretação proativa da Constituição Federal perante os problemas sociais encontrados, criando uma regra de conduta especifica para um entendimento vago da norma legal, considerando-se assim que a decisão tomada pelo STF perante a união homoafetiva,

\footnotetext{
${ }^{4}$ Os onze juízes do tribunal (STF) são chamados de Ministros, apesar de o cargo não ter nenhuma semelhança com os ministros dos órgãos do governo. Eles são nomeados pelo Presidente da República, devendo ser aprovados pelo Senado Federal. A idade para aposentadoria compulsória é de 75 anos.
} 
não deve extrapolar limites impostos pela mesma, mas, todavia, deve procurar resultados mais condizentes com a realidade social.

Ainda, cita-se como ação relacionada aos direitos homossexuais a ADPF 132 (Ação de Arguição de Descumprimento de Preceito Fundamental n.132), proposta em 27 de janeiro de 2008, tendo como base o Decreto Lei ${ }^{\circ} 220$ (estatuto dos servidores civis do Estado do Rio de Janeiro), fundando-se no artigo $33^{5}$.

O artigo acima citado versa sobre a concessão de benefícios previdenciários e assistência social ao servidor e sua família, nota-se assim que interpretação literal deste artigo geraria consequências extremamente vexatórias e discriminatórias para os casais homoafetivos, impedindo o recebimento de benefícios pelos mesmos. Ainda sobre a Ação de Arguição de Descumprimento de Preceito Fundamental 132, pode-se citar o uso do artigo $3^{\circ}$, IV da Constituição Federal de 1988, onde se propõe a promoção do bem de todos, bem como ainda usa-se o direito ao reconhecimento da preferência sexual como uma ramificação de aplicação direta do principio da dignidade da pessoa humana, estendendo-se ao direito à vida privada, sendo assim considerado o uso da sexualidade como uma autonomia pessoal de escolha entre parceiros, interligando-se assim com a liberdade sexual de cada indivíduo. Contudo, ainda fala-se na interpretação normativa do artigo 1.723 do Código Civil como autoriza o Artigo $4^{\circ}$ da Lei de Introdução as Normas do Direito Brasileiro ${ }^{6}$, fazendo-se assim com que o artigo não se torne letra morta de lei, atendendo aos fins sociais a que ele foi destinado, bem como tornando o direito aplicável aos grupos sociais emergentes de uma nova cultura fundada nos costumes da atualidade vigente.

INTERPRETAÇÃO DO ART. 1.723 DO CÓDIGO CIVIL EM CONFORMIDADE COM A CONSTITUIÇÃO FEDERAL (TÉCNICA DA "INTERPRETAÇÃO CONFORME"). RECONHECIMENTO DA UNIÃO HOMOAFETIVA COMO FAMÍLIA. PROCEDÊNCIA DAS AÇÕES. Ante a possibilidade de interpretação

\footnotetext{
5 Art. 33: O poder executivo disciplinará a previdência e a assistência ao funcionário e à sua família, compreendendo:

I-salário família;

II - assistência médica, farmacêutica, dentaria e hospitalar;

IV- financiamento imobiliário;

V- auxilio auxílio-doença;

III - moradia;

VI-auxilio para a educação dos dependentes;

VII- tratamento por acidente em serviço, doença profissional ou internação compulsória para tratamento psiquiátrico;

VIII- auxílio funeral, com base no vencimento, remuneração ou provento;

IX-pensão em caso de morte por acidente em serviço ou doença profissional;

X-plano de seguro compulsório para complementação de proventos e pensões.

Parágrafo único: A família do funcionário constitui-se dos dependentes que, necessária e comprovadamente, vivam a suas expensas (DECRETO-LEI $n^{\circ} 220$ )

6 Art. 4 Quando a lei for omissa, o juiz decidirá o caso de acordo com a analogia, os costumes e os princípios gerais de direito.
} 
em sentido preconceituoso ou discriminatório do art. 1.723 do Código Civil, não resolúvel à luz dele próprio, faz-se necessária a utilização da técnica de “interpretação conforme à Constituição". Isso para excluir do dispositivo em causa qualquer significado que impeça o reconhecimento da união contínua, pública e duradoura entre pessoas do mesmo sexo como família. Reconhecimento que é de ser feito segundo as mesmas regras e com as mesmas consequências da união estável heteroafetiva (BRASIL, 2011).

Após tramitação das ações, reconheceu-se por unanimidade a constitucionalidade da união homoafetiva. O casamento homoafetivo não difere do casamento heteroafetivo em termos legais, pois a documentação necessária, o trâmite e os direitos conjugais são iguais para os dois casos, valendo-se assim do uso do principio da isonomia para a garantia de um direito fundamental.

Ademais, encontra-se em tramitação o Projeto de Lei 1151/95, proposto por Marta Suplicy, que pretende disciplinar o casamento entre pessoas do mesmo sexo. Em seu teor, encontra-se o reconhecimento aos parceiros do direito de composição de renda para aquisição de casa própria e todos os direitos ligados a aquisição de planos de saúde. Porém este Projeto de Lei não visa alterar o estado civil dos indivíduos, pois teria o funcionamento como um contrato. Ainda, encontra-se o Projeto de Lei 5120/13, por tratar-se de projeto mais atualizado, consegue atender as demandas sociais, sendo o mesmo proposto pelo deputado Jean Wyllys, visa reconhecer o casamento entre pessoas do mesmo sexo, opondo-se ao modelo de União Civil, tentando-se ainda dar entrada no projeto de Emenda Constitucional, visando alterar o parágrafo $1^{\circ}$ e $3^{\circ}$ do artigo $226^{7}$ afim da inclusão dos parceiros do mesmo sexo no texto constitucional.

Ainda, no teor do projeto de Emenda Constitucional, afirma-se ser uma evolução social a aceitação do casamento homoafetivo, equiparando-se ainda a conquista do voto pelo público feminino, ainda afirma-se que o projeto tem por objetivo trazer o problema da união homoafetiva para dentro do judiciário, a fim de atingir a igualdade. Contudo, Ainda usa-se para a fundamentação do Projeto de Emenda Constitucional o $\operatorname{artigo} 1^{\circ}$ e o $\operatorname{artigo} 7^{\circ 8}$ da Declaração Universal dos Direitos Humanos, fundando-se na "liberdade de ser quem se é", intrínseca ao ser humano, e ter a certeza que o Estado apenas interfira para proteger esse

\footnotetext{
${ }^{7}$ Art. 226. A família, base da sociedade, tem especial proteção do Estado. $\S 1 .^{\circ}$ O casamento é civil e é gratuita sua celebração. Ele será realizado entre duas pessoas e, em qualquer caso, terá os mesmos requisitos e efeitos sejam os cônjuges do mesmo ou de diferente sexo. $\S 2 .^{\circ} \quad O \quad$ casamento religioso tem efeito civil, nos termos da lei. § 3. ${ }^{\circ}$ Para efeito da proteção do Estado, é reconhecida a união estável entre duas pessoas, sejam do mesmo ou de diferente sexo, como entidade familiar, devendo a lei facilitar sua conversão em casamento.(MARTINS,2015)

${ }^{8}$ Artigo $1^{\circ}$ Todos os seres humanos nascem livres e iguais em dignidade e em direitos, Artigo $7^{\circ}$ "Todos são iguais perante a lei e, sem distinção, têm direito a igual proteção da lei”.
} 
direito, bem como punir quem o cerceá-lo, sendo um indivíduo igual perante a lei, assim fundamentando a liberdade de escolha de sexualidade do individuo, bem como o seu direito à intimidade, assim, também fortalecendo a ideia de proteção perante a lei, porém ainda deparando-se com as diferenças sociais e preconceitos fundados em senso comum, e que acabam sendo aceitos pela lei devido a tratar-se de um grupo social de pequena visibilidade perante os indivíduos.

Este projeto de alteração do Código Civil vem trazer ao parlamento brasileiro o grito de milhões de seres humanos que querem ser livres e iguais em dignidade e em direitos não somente no papel, mas também na prática. Trata-se de pessoas cujos direitos fundamentais são atualmente negados pelo Estado com pretextos inaceitáveis, tão somente por terem uma identidade sexual minoritária, desrespeitando-se assim tanto a promessa da legislação internacional sobre Direitos Humanos quanto a imposição feita pelo Superior Tribunal Federal ao Congresso Nacional de legislar sobre a união estável em todas as suas prerrogativas (ADPF 132 e ADI 4.277). Além da Declaração Universal dos Direitos Humanos (arts. 1, 2 e 7), a igualdade perante a lei e o direito a não sofrer discriminação são reconhecidos na Declaração Americana dos Direitos e Deveres do Homem (art. II), no Pacto Internacional sobre Direitos Civis e Políticos (arts. 2 e 26), na Convenção Americana sobre direitos humanos (art. 1), no Pacto Internacional sobre Direitos Econômicos, Sociais e Culturais (art. 2) e na própria Constituição da República (arts. 3 e 5) (PEC 5120/2013).

Privar os homossexuais do direito a união estável além de caracterizar uma violação de Direitos Fundamentais e Humanos, também caracteriza uma privação de obtenção de vários benefícios que advém da união estável, havendo uma exclusão social devido a proibição de uma celebração de um ato intrínseco à cultura, oprimindo de forma velada os homossexuais, partindo do texto constitucional que considera que todos devem ser heterossexuais.

\begin{abstract}
A proibição do casamento civil entre pessoas do mesmo sexo, todavia, é uma violação dos direitos humanos — dentre os quais o direito à igualdade — do mesmo tipo que a exclusão das mulheres do direito ao voto, a proibição do casamento interracial, a segregação de brancos e negros, a perseguição contra os judeus e outras formas de discriminação e violência que, mais tarde ou mais cedo, emergem à superfície e ficam em evidência como tais. Da mesma maneira que hoje não há mais "voto feminino", mas apenas voto, nem há mais "casamento inter-racial", mas apenas casamento, chegará o dia em que não haja mais "casamento homossexual", porque a distinção resulte tão irrelevante como resultam hoje as anteriores e o preconceito que explicava a oposição semântica tenha sido superado. De fato, nos países em que o casamento homossexual chegou mais cedo, a lembrança das épocas em que era proibido resulta cada dia mais estranha e incompreensível para as novas gerações - PEC 5120/2013 (BRASIL, 2018).
\end{abstract}

Atualmente, encontra-se a resolução $\mathrm{n}^{\circ} 175$ do Conselho Nacional de Justiça, assegurada por decisão do Supremo Tribunal Federal, decreta que os cartórios são obrigados a realizar a cerimônia, vedando em seu artigo primeiro a recusa de autoridade competente a 
realização de união estável entre pessoas do mesmo sexo, assim fazendo-se o uso do principio da isonomia como uma forma de concretização de uma garantia fundamental.

\section{Conclusão}

A partir da pesquisa proposta, considera-se o ativismo judicial uma "ferramenta" do Poder Judiciário perante uma omissão do Poder Legislativo em determinada norma, visando uma maior elasticidade e interpretação da norma constitucional, a fim de garantir a proteção efetiva dos direitos, acredita-se que o ativismo judicial advém, ainda, de uma sociedade em constante mudança e evolução, sendo necessárias adaptações conforme as manifestações sociais, não sendo admitido se viver em um mundo estagnado, onde não há a possibilidade de interpretação textual para o benefício das demandas sociais, sendo o judiciário constantemente provocado com questões de alta complexidade não devendo ser deixadas sem a apreciação judicial devida, fundando-se no principio do acesso à justiça, visando com essa atitude a evolução processual, contando com um processo mais justo e voltado para a realidade vivenciada pelos indivíduos envolvidos.

Ainda, há de se falar que, mesmo que seja uma ferramenta de evolução, o ativismo judicial ainda encontra suas controvérsias na doutrina, fundadas nas consequências que o uso extremo pode representar um perigo para a estrutura dos poderes, ao Estado Democrático de Direito, devido à falta de legitimidade do Poder Judiciário, ainda, uma insegurança jurídica perante as decisões a serem tomadas.

Contudo, a decisão relativa à união estável por casais homoafetivos só veio a acrescentar o que já ocorria na sociedade atual, uma evolução do conceito de relação, onde não há uma necessidade de se considerar o sexo do parceiro em questão, fazendo-se assim com que esse grupo social tenha seu direito reconhecido, obedecendo assim o princípio da dignidade da pessoa humana e da isonomia, implicando na utilização das normas da união estável, antes usada apenas para casais heterossexuais, para os casais homoafetivos, fundando-se assim no argumento pungente que o relacionamento é dotado e caracterizado pelos laços afetivos formados durante o tempo, gerando desdobramentos na vida social e emocional do individuo, assim, o impedimento da realização desse instituto acaba por gerar desdobramentos negativos na vida social, tais como o preconceito, a exclusão massificada do grupo em questão, ainda a impossibilidade da obtenção de vários benefícios advindos do instituto. 
Nesse sentido, cabe-se ressaltar que a união homoafetiva vem ganhando cada vez mais força perante a sociedade atual, muito embora tenhamos ainda uma postura conservadora dos Poderes Legislativo e Executivo; fazendo assim com que as demandas positivas nesse aspecto, acabem por fazer esse grupo sentir-se protegido pelo Estado na figura do Poder Judiciário. Alcançando-se assim, uma maior visibilidade em prol do controle positivo, na intenção de se repelir atitudes discriminadoras e agressivas perante este grupo social fundado em ações positivas (ativistas) que garantam o respeito à diversidade sexual.

\section{Referências}

AQUINO, Yara. CCJ do Senado aprova união estável homoafetiva. Disponível em:<http://agenciabrasil.ebc.com.br/geral/noticia/2017-03/ccj-do-senado-aprova-uniaoestavel-homoafetiva> Acesso em 20 de mar de 2018.

BANDEIRA, Regina. Casamento Homoafetivo: Norma completa. Disponível em: <http://www.cnj.jus.br/noticias/cnj/84740-lei-sobre-casamento-entre-pessoas-do-mesmosexo-completa-4-anos> Acesso em 21 de mar de 2018.

BARROSO, Luís Roberto. Judicialização, ativismo judicial e legitimidade democrática. Anuario Iberoamericano de Justicia Constitucional ISSN 1138-4824, núm. 13, Madrid (2009), págs. 17-32. Disponível em :<file:///C:/Users/Bharbara/Desktop/Downloads/DialnetJudicializacaoAtivismoJudicialELegitimidadeDemocra-5124286\%20(1).pdf> .Acesso em 7 de mar de 2018.

BATISTA, Neimar. PARODI, Ana Cecília. O ativismo judicial como meio para efetivação da função social do processo. In: Âmbito Jurídico, Rio Grande, XIV, n. 85, fev 2011. Disponível em: $\quad<$ http://www.ambitojuridico.com.br/site/index.php?n_link=revista_artigos_leitura\&artigo_id=8985>. Acesso em7 de mar 2018.

BRASIL. Supremo Tribunal Federal. ADI 4.277/DF e ADPF 132/RJ. Julgado em 05 e 06/05/2011. Rel. Ministro Ayres Britto. Disponível em <http://stf.jus.br> Acesso em : 11 out. 2013.

Constituição Federal. Brasília: Senado Federal, 1988. Disponível em: <http://www.planalto.gov.br/ccivil_03/Constituicao/Constituiçao.htm>. Acesso em: 15 maio. 2018.

Código Civil. Brasília: Senado Federal, 2002. Disponível em: <http://www.planalto.gov.br/CCivil_03/Leis/2002/L10406.html> Acesso em15 de maio de 2018.

- Projeto de Emenda Constitucional 5120/2013. Disponível em:< http://www.camara.gov.br/proposicoesWeb/prop_mostrarintegra?codteor=1064244\&filename $=$ PL+5120/2013)> Acesso em 21 de mar de 2018. 
CARMONA, Geórgia Lage Pereira. A propósito do ativismo judicial: superpoder judiciário?. Âmbito Jurídico, Rio Grande, 05 abr. 2015. Disponível em:< http://www.ambitojuridico.com.br/site/?n_link= revista_artigos_leitura\&artigo_id=11605>. Acesso em 20 março 2018.

CARVAlHO, Adriana Pereira Dantas. Casamento homoafetivo. In: Âmbito Jurídico, Rio Grande, XV, n. 107, dez 2012. Disponível em: <http://www.ambitojuridico.com.br/site/?n_link=revista_artigos_leitura\&artigo_id=12599>. Acesso em 20 de mar 2018.

CHAVES, Cristiano. A família da pós-modernidade: em busca da dignidade perdida. Disponível em: < http://www.revistapersona.com.ar/9farias.htm> Acesso em 19 de mar de 2018.

CITTADINO, Gisele. Poder Judiciário, Ativismo judicial e democracia. Revista da Faculdade de Direito de Campos, Ano li, $N^{\circ} 2$ e Ano 111, No 3 - 2001-2002. Disponível em: <https://core.ac.uk/download/pdf/16013577.pdf> Acesso em 6 de mar de 2018.

COSTA, Hélio de Souza. A união homoafetiva e a sua regulamentação no Brasil. Disponível em :<https://jus.com.br/artigos/39874/a-uniao-homoafetiva-e-sua-regulamentacao-no-brasil> Acesso em 21 de mar de 2018.

ESTADO DO RIO DE JANEIRO. Decreto lei $n^{\circ} 220$, Estatuto dos Servidores Civil do Estado Rio do Janeiro. Disponível em: <http://alerjln1.alerj.rj.gov.br/decest.nsf/13a8832c3ad51674832569d0006c75a4/cb7fc6f032ee 6e5683256eb40054bd0e?OpenDocument> Acesso em 21 de mar de 2018.

FERREIRA NETTO, Thayza Rodrigues. O ativismo judicial e suas nuances jurídicas. In: Âmbito Jurídico, Rio Grande, XVIII, n. 138, jul 2015. Disponível em: $<$ http://www.ambito-

juridico.com.br/site/?n_link=revista_artigos_leitura\&artigo_id=15760\&revista_caderno=9>. Acesso em 12 de mar 2018.

GOMES, Eva. As duas faces do Ativismo Judicial. Disponível em: <https://jus.com.br/artigos/40366/as-duas-faces-do-ativismo-judicial> Acesso em 13 de mar de 2018.

GRANJA, Cícero Alexandre. Ativismo Judicial no Brasil como forma de concretização de direitos fundamentais sociais. Disponível em: https://www.editorajc.com.br/ativismo-judicialbrasil-mecanismo-concretizar-direitos-fundamentais-sociais/ Acesso em 20 de dez de 2018.

LOPES, Bruno de Souza; KARLINSKI, Francisco José Gonçalves; CARDOSO, Tiago Cougo. Algumas considerações acerca do ativismo judicial. In: Âmbito Jurídico, Rio Grande, XIII, $\quad$ n. $83, \quad$ dez $2010 . \quad$ Disponível <http://www.ambitojuridico.com.br/site/index.php?artigo_id=8831\&n_link=revista_artigos_1 eitura $>$. Acesso em 10 de mar 2018. 
MARTINS, Renata. União civil e casamento homoafetivo: Entenda a diferença. Disponível em <http://www.ebc.com.br/cidadania/2014/09/uniao-civil-x-casamento-homoafetivoentenda-a-polemica> Acesso em 19 de mar de 2018.

MIGLIAVACCA, Luciano de Araújo. Ativismo judicial e processo civil no estado contemporâneo. Disponível em: <file://C:/Users/Bharbara/Desktop/Downloads/DialnetAtivismoJudicialEProcessoCivilNoEstadoContemporane-5120175.pdf> . Acesso em 5 de mar de 2018.

NEVES, Isabela Dias. Ativismo Judicial frente ao processo civil democrático. Artigo publicado na Revista Magister de Direito Civil e Processual Civil n ${ }^{\circ}$ 47, mar/abr 2012. Disponível em: <http://professorluizclaudioborges.blogspot.com.br/2013/02/ativismojudicial-frente-ao-processo.html> Acesso em 9 de mar de 2018.

ROWEDER, Rainner Jerônimo. União homoafetiva: uma realidade no ordenamento jurídico brasileiro. In: Âmbito Jurídico, Rio Grande, XV, n. 102, jul 2012. Disponível em: <http://www.ambito-

juridico.com.br/site/index.php/?n_link=revista_artigos_leitura\&artigo_id=12029\&revista_cad erno=14>. Acesso em19 de mar 2018.

SALOMÃO. Northon. O ativismo judicial no âmbito do STF. Disponível em: < http://www.administradores.com.br/artigos/academico/o-ativismo-judicial-no-ambito-dostf/106213/>Acesso em 13 de mar de 2018.

SVRITAS. Caroline. Direitos na união homoafetiva. Disponível em:< http://www.revistavisaojuridica.com.br/2017/04/21/direitos-na-uniao-homoafetiva/> Acesso em21 de mar de 2018.

TEIXEIRA, Brenda. A judicialização da política e a união homoafetiva. Disponível em:< http://jusliberdade.com.br/judicializacao-da-politica-e-uniao-homoafetiva/> Aceso em 19 de mar de 2018. 